\title{
Ortaokul 8. sınıf öğrencilerinin cebir bilgileri ve cebirsel düşünme düzeylerinin problem kurma becerileri açısından incelenmesi
}

\author{
Filiz Tuba DİKKARTIN ÖVEZ ${ }^{1, *}$, Büşra Aydın ÇINAR ${ }^{2}$ \\ ${ }^{l}$ Balıkesir Üniversitesi Necatibey Eğitim Fak. Matematik ve Fen Eğitimi Böl., Çağış kampüsü, Balıkesir. \\ ${ }^{2}$ Milli Ĕ̆itim Bakanlığı, Sındırgı, Balıkesir. \\ Geliș Tarihi (Recived Date): 31.03 .2018 \\ Kabul Tarihi (Accepted Date): 20.04.2018
}

\section{Özet}

$\mathrm{Bu}$ araştırmanın amacı, 8. sınıf öğrencilerinin cebir bilgileri ve cebirsel düşünme düzeylerinin problem kurma becerileri açısından incelemektir. Araştırma Bursa ilinde öğrenim gören basit seçkisiz örnekleme yöntemi ile seçilen 200 sekizinci sinı öğrencisi ile gerçekleştirilmiştir. Çalışmada tarama modeli benimsenmiştir. Veri toplama aracı olarak Problem Kurma Testi ve Cebirsel Düşünme Düzeyi Belirleme Ölçeği kullanılmıştır. Verilerin analizinde öğrencilerin kurdukları problemler Silver ve Cai tarafindan geliştirilen veri kodlama şeması temel alınarak puanlanmış, problem kurma beceri puanlarının, sahip oldukları cebirsel düşünme düzeylerine göre anlamlı farklılık gösterip göstermediğini belirlemek amacıyla tek yönlü varyans analizi kullanılmıştır. Ayrıca öğrencilerin cebir bilgilerinin kurdukları problemlere yansımasını belirlemek için geliştirilen rubrik ile ögrencilerin cebir bilgileri, kurdukları problemler kapsamında analiz edilmiş ve her düzeye ilişkin veriler betimsel olarak sunulmuştur. Çalışmanın sonucunda ögrencilerin problem kurma beceri puan ortalamaları ile cebirsel düşünme düzeyleri arasında anlamlı bir farklılık olduğu tespit edilmiştir. Kurulan problemlerden yola çıkarak cebir bilgilerine yönelik yapılan incelemede öğrencilerin \% 18 inin problemleri kurarken matematiksel bilgiyi, sembol ve formül bilgisini doğru tanımladıkları, \% 5.5 inin cebir bilgisini günlük hayatta nasıl kullanılacağına ilişkin bilgi ve beceri transferi yaparak problem kurabildiği \% 14 ünün problemi kurarken verilen duruma ilişkin uygun muhakeme yapabildiği ve uygun problem kurabildiği belirlenmiştir.

Anahtar kelimeler: Problem kurma becerisi, cebirsel dü̈sünme düzeyi, cebir bilgisi, matematik ĕgitimi.

\footnotetext{
*Filiz Tuba DİKKARTIN ÖVEZ, tdikkartin@balikesir.edu.tr, http://orcid.org/0000-0003-2646-5327 Büşra Aydın ÇINAR, busraydinbal@gmail.com, http://orcid.org/0000-0003-0878-1852

\$25. Ulusal Eğitim Bilimleri kongresinde çalışmanın bir bölümü sözel olarak sunulmuştur.
} 


\title{
Assessment of secondary school 8th grade students' algebra knowledge and algebraic thinking levels with regard to problem posing
}

\begin{abstract}
This study aims to assess eight grade students' algebra knowledge and algebraic thinking levels with regard to problem posing. The study sample included 200 eighth graders that were selected using simple random sampling method in Bursa province. This is a survey. Problem Posing Test and Scale on Algebraic Thinking Level were used as data collection tools. Problems posed by students were scored based on data coding scheme developed by Silver and Cai in data analysis. One-way analysis of variance (ANOVA) was used to determine whether problem posing skill scores showed a significant difference by algebraic thinking levels of students. In addition, student's algebra knowledge was analyzed by the rubric developed to determine whether student's algebra knowledge reflect on the problems they posed, and data regarding each level were presented in a descriptive manner. As a result of the study, a significant difference was found between mean scores of students' problem posing skill and algebraic thinking levels. It was found in the examination performed using posed problems on algebra knowledge that $18 \%$ of the students described mathematical, symbol and formula knowledge correctly when posing problems, 5.5\% were able to pose problem transforming knowledge and skills regarding how to use algebra knowledge in daily life, and $14 \%$ were able to make judgment regarding given situation when posing problem and pose a suitable problem.
\end{abstract}

Keywords: Problem posing skill, algebraic thinking level, algebra knowledge, mathematics education.

\section{Giriş}

Problem kurma matematik öğrenme ve öğretiminin önemli bir bileșenidir. Problem kurma, öğrencilerin somut durumlara yönelik olarak yapmış oldukları kişisel yorumları ve bunları anlamlı matematiksel problemler olarak biçimlendirmeyi içeren bir süreçtir. $[1,2]$. Problem kurma kavramsal anlama, yaratıcılık, problem çözme ve muhakeme becerileriyle ilişkili olup bu bileşenlerin gelişimine katkı sağlamaktadır. Ayrıca öğrencilerin matematiksel bilgi ve yetenekleri hakkında bilgi veren önemli bir değerlendirme aracıdır [3]. Problem kurma ayrıca matematik öğretiminin merkezinde yer alan problem çözme becerisiyle de pozitif yönde güçlü bir ilişki içerisindedir. Çünkü problem çözme süreci, problem kurma becerilerinin gelişimini de etkileyen süreci kapsamaktadır. Problem kurma, belirli bir problemden [4] ya da belirli bir durumdan veya deneyimlerden yeni bir problem yaratılması olarak tanımlanabilir. Problem kurma öğrencilerin yaratıcılığını artırmanın bir aracı olarak kullanılabileceği gibi [5] matematiksel bilgiyi aktarma yeteneğinin gelişmesine yardımcı olarak da kullanılabilir [6]. Problem kurma matematiksel düşünme, matematiksel işlem becerisi gibi konularda öğrencilerin anlama düzeylerini belirlemek için tek başına kullanılabilecek bir ölçme yoludur [7]. Bu açıdan problem kurma kendi başına hem bir 
öğretim hem de değerlendirme aracı olarak düşünülebilir. Problem kurma yöntemini kullanarak yapılan değerlendirmeler öğretmene detaylı bilgi vermede etkili bir yoldur [8]. Bu doğrultuda öğretmen, problem kurma görevinin dersin amacı ile nasıl ilişkili olduğunu düşünerek öğrencilerin nasıl değerlendirileceğine karar verebilir.

Matematiğin temel taşlarından birisi olan problem çözme sürecinin yaratıcılık açısından en üst düzeyi olarak kabul edebileceğimiz problem kurma, öğrencilerin gerçek potansiyellerini, matematiksel düşünme yapılarını ve becerilerini ortaya koymayı sağlayan bir süreçtir. Bu süreçte başarılı olan öğrenci, matematiksel keşif ve araştırma yapmanın heyecanını deneyimleyebilir. Bu kapsamda problem kurmanın pedagojik yararları düşünüldüğünde sadece bir sınıf içi değerlendirme aracı olarak değil öğrencilerin düşünme süreçlerini anlayışlarını ve matematiksel yetkinliklerini incelemek içinde bir değerlendirme aracı olarak kullanılması önerilebilir. Çünkü problem kurma aktiviteleri, öğrencilerin kendilerine sunulan durumlarla etkileşime girmelerini sağlayarak kendi anlayışları, matematik bilgileri ve becerileri ile tutumları hakkında çok şey ortaya koymaktadır [9].

Ayrıca öğrenciler kendi problemlerini oluşturduklarında matematik bilgisini geliştirebilmekte, eleştirel düşünebilmekte ve belirli matematik kavramları hakkında keşfederek hesaplama becerilerini geliştirebilmektedirler. Bu doğrultuda problem kurma eleştirel düşünme için gelişimsel bir araç olarak da düşünülebilir [10]. Problem kurma sürecinde öğrencilerin sadece matematiksel olarak düşünmekle kalmayıp, yeni bir matematik problemlerini yeniden formüle edip üretirken yaratıcı düşünmeleri de gerekmektedir [11]. Problem kurma üzerine yapılan araştırmalar incelendiğinde problem kurma sürecinin öğrencilerin bilgisi, problem çözme becerileri, problem kurma becerileri, yaratıcılık ve matematiğe yönelik tutumları üzerinde olumlu sonuçları olduğu [11-14], problem kurma etkinliklerinin matematik ve matematik öğretimine yönelik tutum ve inançlar üzerinde olumlu etkilerinin olduğu [15] öğrenciler yeni problemler kurduklarında, arkadaşlarıyla paylaşımda bulundukça sorumluluk duygularının arttığını belirlemişlerdir [16].

Uygulanan Ortaokul matematik dersi öğretim programı matematiksel becerilerin gelişmesinde önemli yapı taşları olan problem kurma ve çözme becerilerini geliştirmeyi hedefleyen bir anlayışa sahiptir. $\mathrm{Bu}$ doğrultuda matematik eğitiminin temel amaçlarından biri öğrencilerin problem çözme becerilerini geliştirmek olarak kabul edilmiş, problem çözme; öğretim programı içerisinde yer alan her konu için geliştirilmesi beklenen temel bir beceri olarak ele alınmıştır. Programda öğrencilerin problem çözme becerilerini geliştirmeye yönelik çalışmalarda, problem kurmayı da içeren bir sürecin izlenmesi gerektiği vurgulanmış, her sınıf düzeyinde problem kurma becerisini geliştirmeyi hedefleyen kazanımlara yer verilmiştir [1].

Bir beceri olarak geliştirilmesi hedeflenen problem kurma aslında kendi içinde öğrenci bilgisini ortaya koyan bir değerlendirme aracı gibi veri sağlamaktadır. Problem kurma ayrıca öğrencilerin matematiksel düşünmelerinin güçlü ve önemli yönlerini ya da eksikliklerini ortaya koymaktadır. Çünkü öğrencinin problem kurabilmesi için, denklem, durum ya da cebirsel ifadelerde yer alan değişkenler arasındaki ilişkileri belirlemesi gerekmektedir [17].

$\mathrm{Bu}$ sürecin içindeki en önemli faktör ise matematiğin dili olarak tanımlanan cebir ve cebir bilgidir. Harfin anlamını bilen, denklemleri, değişkenleri farklı gösterimleri ve 
bunlar arasındaki ilişkileri doğru anlayabilen öğrencinin yani cebirsel düşünebilen bir öğrencinin problem kurma sürecinde daha başarılı olabileceği düşünülmektedir. Çünkü cebirsel düşünme içerisinde akıl yürütme, gösterimleri kullanma, değişkenleri anlama, sembolik gösterimlerin anlamını açıklama, matematiksel fikirlerin gelișimi için modellerle çalışma, gösterimler arasında dönüşüm yapma gibi becerileri içeren bir düşünme biçimidir. Ayrıca Problem kurma sürecinin öğrencilerin cebir bilgisi ve cebirsel düşünme becerileri konusunda derin bilgiler verebileceği düşünülmektedir. Matematiksel düşünmenin gelişiminde önemli bir yeri olan cebirsel düşünmenin öğretim programlarındaki uygulamaları önem taşımaktadır. Böyle bir ihtiyaç matematik öğretim programının cebirsel düşünmeyi ne ölçüde geliştirdiği sorusunu akla getirmektedir. Yapılan araştırmalar, Ortaokul ve Lise matematik öğretim programları kapsamında yer alan cebir öğrenme alanı kazanımlarına ulaşılma düzeyinin oldukça yetersiz olduğunu, kazanımlara ulaşılma düzeylerinin altıncı sınıflarda $\% 57.1$, yedinci siniflarda $\%$ 55.5, sekizinci siniflarda \% 44.4, dokuzuncu siniflarda \% 0, onuncu siniflarda $\% 9.3$, on birinci siniflarda $\% 23.8$ ve on ikinci sinıflarda $\% 40$ oraninda olduğunu göstermektedir. Bu sonuçlar ülkemizde cebir bilgisinin incelenmesini gerekli kılmaktadır [18].

$\mathrm{Bu}$ süreçte sınıf içi bir değerlendirme aracı olarak kullanılmasının yanında biçimlendirici bir değerlendirme aracı olarak da kullanılması önerilen problem kurma [9], hem öğretmenlere hem de öğrenicilere, ne kadar öğrenmenin gerçekleştiğini gösterebilir ve öğrenme sürecine yönelik sonuçları ortaya çıkarabilir. Bu doğrultuda matematiksel düşünmenin önemli bir unsuru olan cebirsel düşünme ve matematiğin dili olan cebir bilgisinin değerlendirilmesinde problem kurma sürecinin sağlayacağ biçimlendirici değerlendirme açısından önemli görülmektedir. Bu nedenle araştırmanın amacı, cebir ve değişken bilgisinin ilk temellerinin atıldığ 1 Ortaokul Matematik Dersi Öğretim Programı uygulamalarına katılan 8. sınıf öğrencilerinin cebir bilgileri ve cebirsel düşünme düzeylerinin problem kurma becerileri açısından incelemektir. $\mathrm{Bu}$ doğrultuda problem kurma becerileri bir değerlendirme aracı olarak düşünülmüş öğrencilerin cebir bilgilerinin ve cebirsel düşünme düzeylerinin kurdukları problemlere yansımaları incelenmiştir.

$\mathrm{Bu}$ amaç kapsamında aşağıdaki araştırma sorulara yanıt aranmıştır.

- 8. Sınıf öğrencilerinin problem kurma becerileri, sahip oldukları cebirsel düşünme düzeylerine göre anlamlı farklılık göstermekte midir?

- Farklı cebirsel düşünme düzeylerine sahip 8. Sınıf öğrencilerinin cebir bilgilerinin kurdukları problemlere yansıması nasıldır.?

\section{Yöntem}

\subsection{Araştırmanın modeli}

Araştırmada, öğrencilerin mevcut cebir bilgilerinin problem kurma açısından incelenmesi söz konusu olduğundan, tarama modeli benimsenmiştir. Tarama modeli, geçmişte ya da halen var olan bir durumu varolduğu şekliyle betimlemeyi amaçlayan araştırma yaklaşımlarıdır [19]. 


\section{2. Çalışma grubu}

Araştırmanın çalışma grubunu Bursa ili Kemalpaşa mahallesinde 2016-2017 eğitim öğretim yılında Milli Eğitim Bakanlığına bağlı 3 ortaokulda öğrenim gören basit seçkisiz örnekleme yöntemi ile rastgele seçilen 200 sekizinci sınıf öğrencisi oluşturmaktadır. Çalışma grubunda 102 kız, 98 sayıda erkek öğrenci yer almaktadır.

\subsection{Veri toplama araçları}

Araştırma da öğrencilerin cebirsel düşünme düzeylerini belirlemek amacıyla CSMS "Concepts in Secondary Mathematics and Science" ve K.M. Hart tarafından 1998 yılında geliştirilen [20]. Cebirsel düşünme düzeyi ölçeği kullanılmıştır. Cebir testi dört cebirsel düşünme düzeylerini ölçen 27 açık uçlu sorudan oluşmaktadır. Öğrencilerin cebirsel ifadeleri anlama düzeylerini ortaya koymak amacıyla geliştirilen ölçekte elde edilen veriler 1şığında cebirsel düşünme düzeyleri dört aşamada incelenmektedir [21]

Düzey 1: Aritmetik işlemlerin sonucunda bir harfin değerini bulma, harfleri birer nesne olarak algılayarak bir problemi sonlandırma ve sorunun içeriğinde bulunan harflere rağmen bu harflere değer vermeden bir işlemi sonlandırma becerilerini içermektedir.

Düzey 2: Bu düzey düzey 1 deki gibi aritmetik işlemlerin sonucunda bir harfin değerini bulma, harfleri birer nesne olarak algılayarak bir problemi sonlandırma ve sorunun içeriğinde bulunan harflere rağmen bu harflere değer vermeden bir işlemi sonlandırma becerilerini içermektedir. Bu düzeydeki öğrencilerden birinci düzeyle aynı soyutluk derecesinde olmasına rağmen daha karmaşık sorulara yanıt bulmaları beklenmektedir.

Düzey 3: Harflerin belli bir bilinmeyen olarak kullanılmasını becerilerini içermektedir.

Düzey 4: Harflerin belli bir bilinmeyen olarak kullanılması becerilerini içererek daha karmaşık soruların çözümünü gerektiren cebirsel becerileri içerir.

Öğrencilerin problem kurma becerilerinin belirlenmesi amaciyla Stoyanova ve Ellerton [22] tarafından geliştirilen; serbest, yarı-yapılandırılmış ve yapılandırılmış problem durumlarını içeren Problem Kurma Ölçeği araştırmacılar tarafından geliştirilmiştir. Ölçekte 2 serbest, 2 yarı-yapılandırılmış ve 2 yapılandırılmış problem durumlarına uygun olarak hazırlanmış toplam 6 açık uçlu soru yer almaktadır. Ölçekte yer alan sorular seçilirken öğretim programında yer alan kazanımlar dikkate alınmış ve ilgili araştırmalar incelenmiştir [23,24].

Ölçeğin kapsam geçerliğini belirlemek için 2 matematik eğitimi alan uzmanı ve 6 matematik öğretmeninin görüşlerine başvurularak seçilen soruların problem kurma durumları, dil, seviye ve içerik bakımından uygunluğu incelenmiş ve ön deneme ölçeği oluşturulmuştur. Her madde uzmanlar tarafından "madde hedeflenen yapıyı ölçüyor", "madde yapı ile ilişkili ancak gereksiz", "madde hedeflenen yapıyı kısmen ölçüyor", "madde hedeflenen yapıyı ölçmez" şeklinde derecelendirilmiştir. Uzman görüşleri doğrultusunda her maddeye ait kapsam geçerlik oranları elde edilmiştir. Kapsam geçerlik oranları, maddeye ilişkin "gerekli" şeklinde görüş belirten uzman sayısının maddeye ilişkin görüş belirten uzman sayısına oranının 1 eksiği ile elde edilmiştir [25]. Elde edilen kapsam geçerlilik oranı 0 veya negatif ise madde ölçekten atılmış, değer pozitif ise kapsam geçerlilik oranı minimum değeri .78 ve üstü ise anlamlı kabul edilerek madde ön deneme ölç̧eğine dahil edilmiştir. Maddelere ilişkin elde edilen 
kapsam geçerlilik oranlarının (KGO) ortalaması alınarak ölçeğin tamamına ait Kapsam Geçerlik İndeksi (KGİ) hesaplanmıştır [26]. Ölçeğin KGİKGO (.78) kapsam geçerliğinin istatiksel olarak anlamlı olduğu sonucuna ulaşılmıştır. Uzman görüşlerine göre elde edilen KGO değerine bakılarak bazı maddeler ölçekten çıkartılmış, ön deneme ölçeği elde edilmiştir. Ön deneme ölçeğinde yer alan soruların anlaşılırlığı, açıklığı, şekillerin anlaşılırlığı açısından değerlendirmesi amacıyla çalışma grubu dışında yer alan 20 sekizinci sınıf öğrencisine uygulanarak anlaşılmasında sorunlar olduğu tespit edilen sorular düzeltilmiş ve 6 sorudan oluşan ölçeğe son hali verilmiştir. Ölçekte yer alan sorulara ilişkin açıklamalar Tablo 1'de sunulmuştur.

Tablo 1. Problem kurma ölçeğinde yer alan soruların problem durumlarına göre sinıflandirilması.

\begin{tabular}{|c|c|c|}
\hline $\begin{array}{c}\text { Problem Kurma } \\
\text { Durumları }\end{array}$ & Özellikleri & İçeriği \\
\hline 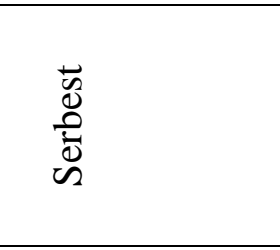 & $\begin{array}{lr}\text { Öğrencinin } & \text { suni ya da } \\
\text { doğal bir durumdan bir } \\
\text { problem üretmesinin } \\
\text { istendiği } \quad \text { durumdur. } \\
{[22,28] \text {. }}\end{array}$ & $\begin{array}{l}\text { 1.Günlük yaşantınızda karşılaştığınız } \\
\text { olaylardan yaralanarak cebirsel } \\
\text { ifadelere yönelik problem kurunuz ve } \\
\text { çözünüz. } \\
\text { 2. Örüntü içeren bir problem kurunuz. }\end{array}$ \\
\hline 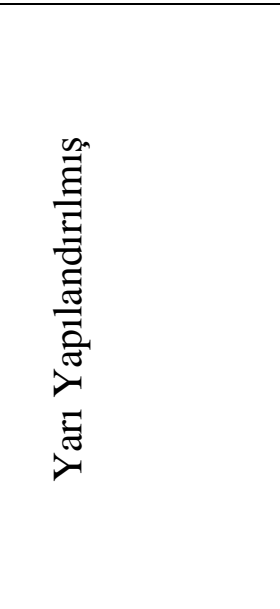 & $\begin{array}{l}\text { Açık bir durumun } \\
\text { verilerek bu durumda } \\
\text { yer alan yapının } \\
\text { keşfedilmesinin } \\
\text { istenildiği durumdur. } \\
\text { Bunu bilgi, beceriler ve } \\
\text { kavramları ve daha } \\
\text { önceki matematiksel } \\
\text { deneyimlerinden elde } \\
\text { ettikleri ilişkileri } \\
\text { kullanarak öğrenciler } \\
\text { tamamlarlar }[22,28]\end{array}$ & $\begin{array}{l}\text { 3. } \\
\text { 1.adım 2.adm } \\
\text { a) 10. şekilde kaç tane daire } \\
\text { olmalıdır? Açılayınız } \\
\text { b) "n." şekildeki daire sayısını } \\
\text { bulmak için bir formül bulunuz. } \\
\text { c) Verilen örüntüye uygun bir } \\
\text { problem kurunuz } \\
\text { 4. } \frac{2(x-4)}{\pi}=x-4 \text { Denklemine uygun bir } \\
\text { problem kurunuz. }\end{array}$ \\
\hline 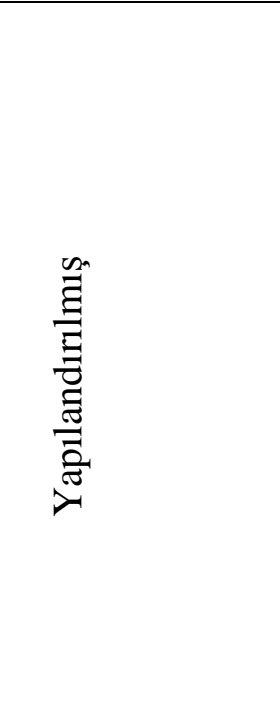 & $\begin{array}{l}\text { problem kurma } \\
\text { etkinliklerinin özel bir } \\
\text { probleme dayalı olarak } \\
\text { gerçekleştirilme } \\
\text { durumudur [22,28] }\end{array}$ & $\begin{array}{l}\text { 1) Bir araba kiralama şirketi kiraladığı } \\
\text { bir araba için günlük } 70 \mathrm{TL} \text { ve arabanın } \\
\text { kullanıldığı km başına } 4 \text { TL para } \\
\text { istemektedir. Bu şirketten araba } \\
\text { kiralayan Ahmet } 5 \text { gün sonra arabayı } \\
\text { teslim ediyorsa ne kadar ödemiş } \\
\text { olabilir? Yanıtınızı nasıl bulduğunuzu } \\
\text { açıklayın. Bu bilgileri kullanarak farklı } \\
\text { bir problem kurunuz. } \\
\text { 2) Tolga'nı bilyelerinin sayısı } \\
\text { Arda'nın bilyelerinin sayısından } 65 \\
\text { tane fazladır. İkisinin bilyeleri toplamı } \\
\text { nasıl bulunur? Yanıtınızı nasıl } \\
\text { bulduğunuzu açıklayın. Bu bilgileri } \\
\text { kullanarak farklı bir problem kurunuz }\end{array}$ \\
\hline
\end{tabular}


Tablo 1 incelendiğinde Serbest, yarı yapılandırılmış ve yapılandırılmış problem kurma durumlarına ilişkin ikişer açık uçlu sorunun yer aldığı görülmektedir. İlgili problemlerin örüntü, cebirsel ifade ve cebirsel ilişki içeren bir duruma uygun olarak problem kurmaya yönelik çalışmaların yer aldığı görülmektedir.

\subsection{Verilerin analizi}

Araştırmanın birinci alt problemi doğrultusunda, öğrencilerin problem kurma becerilerini belirlemek amaciyla uygulanan "Problem Kurma Testi" inden elde edilen veriler Silver ve Cai tarafından geliştirilen veri kodlama şeması kullanılarak Turhan tarafından geliştirilen puanlama yönergesine göre değerlendirilmiştir. Buna göre ölçekte yer alan problem kurma sorularına verilen yanıtlar aşağıdaki biçimde puanlanmıştır. Elde edilen puanlar; problem kurma becerisi kapsamında değerlendirilmişsir [17,29].

Cevap Matematiksel bir problem değilse "0" puan

$>$ Cevap sadece matematiksel bir problem ise 3 puan

$>$ Cevap sadece matematiksel bir problem ancak istenilen yönde kurulmamışsa 3 puan

$>$ Cevap hem matematiksel problem hem de istenilen yönde kurulmuşsa 6 puan

$>$ Cevap istenilen yönde kurulan matematiksel bir problem ancak çözülemiyorsa 6 puan

$>$ Cevap istenilen yönde kurulan matematiksel bir problem ise ve çözülebiliyorsa 10 puan

Öğrencilerin cebirsel düşünme düzeylerini belirlemek amacıyla uygulanan "Cebirsel Düşünme Düzeylerini Belirleme Ölçeğinde" yer alan sorular doğru yanıtlar için 1, yanlış yada boş yanıtlar için 0 puan verilerek değerlendirilmiştir Öğrenciler ölçekten 0 ile 27 arasında puan alabilmektedirler. Hart, bir öğrencinin düzeyini belirlemek için öğrencinin bu düzeyde yer alan soruları doğru cevaplandırıp daha ileri safhadaki soruları cevaplandırmaları halinde karar vermek gerektiğini belirtmiştir [21]. Bir düzeyde yer alan soruların en az 2/3'ünü doğru yanıtlayan öğrencinin bu düzeyin özelliklerini taşıdığına karar verilmektedir. Öğrencilerin problem kurma beceri puanlarının, sahip oldukları cebirsel düşünme düzeylerine göre anlamlı farklılık gösterip göstermediğini belirlemek amacıyla tek yönlü varyans analizi kullanılmıştır. Farklı cebirsel düşünme düzeylerine sahip 8. Sınıf öğrencilerinin cebir bilgilerinin kurdukları problemlere yansımasını belirlemek için geliştirilen rubrik ile öğrencilerin cebir bilgileri, kurdukları problemler kapsamında analiz edilmiş ve her düzeye ilişkin veriler betimsel olarak sunulmuştur (Ek-1). Rubrik geliştirme sürecinde ilk olarak cebir bilgisini değerlendirme ve cebir bilgisinin bileșenleri ile ilgili literatür taraması yapılmıştır. Literatürde cebir bilgisinin değerlendirilmesi ile ilgili kuramsal temeller şöyledir. Cebir bilgisini oluşturan bileşenler konusunda pek çok gruplama mevcuttur. Örneğin Li, cebire ilişkin bilgi kategorilerini; temel kavramlar, temsiller, cebirsel içeriğin gelişimi, cebirsel uygulamalar, cebirsel dil ve temel cebirsel işlemler, muhakeme ve ispat olarak gruplandırılmıştır [30].

Okul cebiri ise pek çok öğretim programında bir öğrenme alanı olarak ele alınmaktadır. $\mathrm{Bu}$ öğrenme alanları kapsamında okul cebir bilgisinin içeriğinin örüntü, değişken, eşitlik ve eşitsizlik, denklem, eğim, doğrusal fonksiyonlar ve grafikleri ana kavramları üzerine yoğunlaştığı görülmektedir. Ortaokul matematik öğretim programı cebir öğrenme alanı kazanımları incelendiğinde ise programda temel olarak değişken, Örüntü, eşit işareti-eşitlik, eşitsizlik, denklem kavramlarını temel alarak şekillendiği 
görülmektedir. Cebir bilgisini değerlendirmeye yönelik olarak yapılan çalışmalar, raporlar ve öğretim programlarında oluşturulan değerlendirme ölçekleri incelendiğinde cebir bilgisinin bileșenlerinin; harfi değişken olarak tanıma, cebirsel ifadelerle işlem yapma, cebirin dilini kullanabilme, sembollerin anlamını bilme, aritmetiği genelleştirmek için örüntüleri kullanabilme örüntüleri genelleyebilme, denklem kurma ve çözme, eşit işaretinin anlamını cebirsel olarak bilme, problem çözme ve kurma sürecinde cebir dilini kullanabilme kategorileri altında incelendiği görülmektedir [1-2]. NCTM standartlarına göre problem çözme becerilerinin değerlendirilmesi; öğrencilerin problem çözmede matematiği kullanma becerisini değerlendirmek olarak tanımlanmış ayrıca öğrencilerin problemleri matematiksel ifadelere dönüştürmesi, problem çözümlerini yaparak sonucu doğrulaması ve genelleme yaparak yeni problemleri kurması matematiği kullanma becerisinin göstergeleri arasında gösterilmiştir [31]. Bu temelden hareketle araştırmada öğrencilerin kurdukları problemlerin matematik, dolayısıyla özelde cebir bilgisini yansıttığı düşüncesinden hareketle yapılan literatür çalışması sonucunda problem kurma bağlamında cebir bilgisini ölçme rubriğinin boyutları belirlenmiștir. Buna göre problem kurma, matematiksel bilgiyi tanımlama, cebir bilgisini günlük hayatla ilişkilendirme, harfi değişken olarak algılama, denklem, genelleme, muhakeme etme (tümevarım, tümdengelim, orantısal akıl yürütme v.b.), eşit işareti ve ilişkisel düşünme boyutların belirlenerek taslak maddeler oluşturulmuştur. İki matematik eğitimi alan uzmanının görüssleri alınarak maddelerde gerekli düzeltmeler yapılmıştır. Alan uzmanları, ölçüt maddelerini açıklığg ve anlaşılırlığı, içeriğinin kendi amacıyla sınırlı olması, performans düzeyinin başarı farkını doğru yansıtacak nitelikte olması ölçülmek istenilen özelliklerin rubrikte yer alması gibi unsurlarda rubrik maddelerini değerlendirmişlerdir. Taslak rubrik için ayrıca 50 öğrencinin problem kurma kağıtları incelenmiş elde edilen veriler incelenerek rubrikte yer alan işlevsiz maddeler atılmıştır. Ölçeğin güvenirliği için 50 öğrencinin problem kurma kağıtları alan uzmanlarınca rubrik çerçevesinde değerlendirilmiş veriler dereceli puanlama anahtarında, puanlayıcılar arası uyuşmanın hesaplanmasında kullanılan yöntemlerden Kappa katsayısı değerlendirilmiştir. (Tablo 2) Ağırlıklı Kappa analizleri yapılarak rubriğe ait güvenirlik sonuçları elde edilmiştir. Kappa katsayısından elde edilen veriler "Zayıf uyuşma" <= .20; Kabul edilebilir uyuşma" = .20- .40 ; "Orta derecede uyuşma" = $.40-.60$; "İyi uyuşma" =.60-.80; "Çok iyi uyuşma" $=.80-1.00$ " olarak yorumlanmaktadır [32].

Tablo 2. Rubrik boyutlarına göre puanlayıcılar arası uyuma ilişkin ağırlıklı kappa katsayısı sonuçları.

\begin{tabular}{|l|c|c|}
\hline \multicolumn{1}{|c|}{ Ölçütler } & $\begin{array}{c}\text { Ağırlıklı Kappa } \\
\text { Değeri }\end{array}$ & $\begin{array}{c}\text { Öğrenci } \\
\text { Sayısı }\end{array}$ \\
\hline $\begin{array}{l}\text { Problemi kurarken doğru strateji ve yaklaşımı } \\
\text { belirleyebilme }\end{array}$ & $0.741^{*}$ & 50 \\
\hline Matematiksel bilgiyi doğru tanımlama & $0.812^{*}$ & 50 \\
\hline Cebir bilgisini günlük hayatla ilişkilendirme & $0.741^{*}$ & 50 \\
\hline Harfin değişken olarak algılaması & $0.655^{*}$ & 50 \\
\hline Denklem bilgisi & $0.651^{*}$ & 50 \\
\hline Genelleme & $0.745^{*}$ & 50 \\
\hline Muhakeme & $0.778^{*}$ & 50 \\
\hline Eşit işareti ve ilişkisel düşünme & $0.692^{*}$ & 50 \\
\hline
\end{tabular}

*.01 düzeyinde anlamlıdır. 
Tablo2'de puanlayıcılar arası uyuma ilişkin Ağırlıklı Kappa Katsayısından elde edilen güvenirlik sonuçlarına yer verilmiştir. Sonuçların .01 düzeyinde anlamlı olduğu bulunmuştur. Geliştirilen rubriğin Cronbach Alfa güvenirlik katsayısı 0.95 olarak belirlenmiştir. Buna göre Ağırlıklı Kappa Katsayısı Matematiksel bilgiyi doğru tanımlama alt boyutunda uyuşmanın çok iyi uyuşma, diğer boyutlardaki uyuşmaların ise iyi uyuşma olduğu görülmektedir.

\section{Bulgu ve yorumlar}

Araştırmada belirlenen araştırma problemleri doğrultusunda ortaokul" 8. sınıf öğrencilerinin problem kurma becerileri puanlarının, sahip oldukları cebirsel düşünme düzeylerine göre anlamlı farklılık göstermekte midir?" sorusuna yanıt aramak için yapılan tek yönlü varyans analizi (ANOVA) sonuçları betimsel veriler Tablo 3 ve Tablo 4 de verilmektedir.

Tablo 3. Sekizinci Sınıf öğrencilerinin problem kurma beceri puanlarına ilişkin betimsel veriler.

\begin{tabular}{|c|c|c|c|}
\hline Cebirsel düşünme düzeyleri & $\mathrm{N}$ & $\bar{X}$ & $\mathrm{~S}$ \\
\hline Düzey 0 & 66 & 3.55 & 6.53 \\
\hline Düzey 1 & 39 & 11.26 & 15.07 \\
\hline Düzey 2 & 39 & 10.10 & 11.33 \\
\hline Düzey 3 & 56 & 13.86 & 10.84 \\
\hline Toplam & 200 & 9.22 & 11.49 \\
\hline
\end{tabular}

Tablo 4. Problem kurma becerileri puanlarının cebirsel düşünme düzeylerine göre karşılaştırılmasına ilişskin ANOVA sonuçları.

\begin{tabular}{|c|c|c|c|c|}
\hline Varyansın Kaynağı & df & sd & F & p \\
\cline { 1 - 2 } Gruplar arası & 3 & 1173.83 & \multirow{2}{*}{10.10} & .000 \\
\cline { 1 - 2 } Grup içi & 196 & 116.13 & & \\
\hline Toplam & 199 & & & \\
\hline
\end{tabular}

Elde edilen veriler incelendiğinde katılımcıların \% 33 ünün düzey 0 da, \% 19,5'inin düzey 1 de, \% 19,5'inin düzey 2,\% 28'inin düzey 3 de yer aldığ1, düzey 4 de ise hiçbir öğrencinin bulunmadığı gözlenmektedir. Bu sonuç öğrencilerin \% 87 sinin düzey 2 ve altında yer alarak harfi değişken olarak kullanamadıklarını, değişkeni ancak bir nesne olarak değerlendirebildiklerini göstermektedir. Tablo 3' de yer alan ortalamalar incelendiğinde, farklı cebirsel düşünme düzeylerine sahip öğrencilerin problem kurma beceri puan ortalamalarının Düzey 0 için 3,55, Düzey 1 için 11.26, Düzey 2 için 10.10, Düzey 3 için 13,86 olduğu görülmektedir. Ortalamalar arasında gözlenen farklılığın anlamlı olup olmadığını belirlemek için yapılan ANOVA sonuçlarına göre öğrencilerin problem kurma beceri puan ortalamaları ile cebirsel düșünme düzeyleri arasında anlamlı bir farkl1lık olduğu tespit edilmiştir. $[\mathrm{F}(3-196)=10.10: \mathrm{p}<.05]$. Anlamlı çıkan $\mathrm{F}$ değerleri için farkın kaynağını belirlemek üzere çoklu karşılaştırma testlerinden Schefee Testi kullanılmıştır. Scheffe testinin sonuçları Tablo 5'de verilmiştir. 
Tablo 5. Öğrencilerin problem kurma puanlarına ilişkin Scheffe testi sonuçları.

\begin{tabular}{|c|c|c|c|}
\hline (I) Düzey & (J) Düzey & (I-J) Ortalama Fark1 & $\mathrm{p}$ \\
\hline \multirow{2}{*}{ Düzey 0 } & Düzey1 & $-7.71^{*}$ & $.00^{*}$ \\
\cline { 2 - 4 } & Düzey2 & -6.55 & $.03^{*}$ \\
\hline \multirow{2}{*}{ Düzey1 } & Düzey3 & -10.31 & $.00^{*}$ \\
\cline { 2 - 4 } & Düzey2 & 1.15 & .97 \\
\hline \multirow{2}{*}{ Düzey 2 } & Düzey3 & -2.60 & .72 \\
\hline
\end{tabular}

$* \mathrm{p}<.05$

Tablo 3 ve Tablo 5'e göre düzey 0 da yer alan öğrencilerin düzey 1,düzey 2 ve düzey 3 de yer alan öğrencilerden oldukça düşük puan ortalamasına sahip olduğu belirlenmiştir. $\mathrm{Bu}$ verilere göre problem kurma beceri puan ortalamaları en yüksek olan grup, düzey 3 , en düşük olan grup ise düzey 0 olarak bulunmuştur. Farklılığın hangi gruptan kaynaklandığına yönelik olarak yapılan Scheffe Testi sonuçları incelendiğinde düzey 0 düzey 1 , düzey 0 - düzey 2 , düzey 0 -düzey $3(\mathrm{p}<.05)$ arasında puan ortalamalar açısından farklılığın anlamlı olduğu, farklılığın düzey 0 dan kaynaklandığı belirlenmiştir. Buna göre öğrencilerin sahip oldukları cebirsel düşünme düzeyinin problem kurma başarılarını etkilediği cebirsel düşünmesi düşük düzeyde olan grubun problem kurmada başarısız olduğu söylenebilir.

Araştırmada ikinci olarak farklı cebirsel düşünme düzeylerine sahip 8. sınıf öğrencilerinin cebir bilgileri problem kurma süreci açısından incelenmiştir. Problem kurma ölçeğinden elde edilen veriler rubrik ile değerlendirilmiştir. Problem kurma ölçeğinde yer alan verilerin puanlama yönergesi kapsamında yapılan incelemede araştırmaya katılan öğrencilerin ölçekte yer alan problem kurma sorularından elde ettikleri puan ortalamaları Tablo 6'da verilmektedir.

Tablo 6. Problem kurma ölçeğinde yer alan problem kurma durumlarına göre puan ortalamaları.

\begin{tabular}{|l|c|c|}
\hline Problem Kurma Durumları & N & X \\
\hline Serbest tip & 200 & 2.08 \\
\hline Yarı yapılandırılmış & 200 & 1.80 \\
\hline Yapılandırılmış & 200 & .73 \\
\hline
\end{tabular}

Her problem durumundan 2 şer sorunun yer aldığı ölçekte bir sorudan maksimum 10 puan alınabilmektedir. Bu kapsamda Tablo 6 deki veriler incelendiğinde, öğrencilerin serbest tipte olan problem kurma sorularından ortalama 2.08, yarı yapılandırılmış grupta yer alan olan problem kurma sorularından ortalama 1.80, yapılandırılmış grupta yer alan problem kurma sorularından 0.73 ortalama puana ulaşabildikleri görülmektedir.

Problem kurma ölçeğinden elde edilen her problem geliştirilen rubrik ile değerlendirilmiş, rubrikte yer alan boyutlara ilişkin öğrencilerin kurdukları problemlerden yola çıkarak cebir bilgileri incelenmiştir. Rubrikte yer alan her boyuttan en az 0 en çok 2 puan alınabilmektedir. Düzeylere göre problem kurma ölçeğinin rubrik boyutlarına göre incelenmesi ile elde edilen puanlar Tablo 7'de verilmektedir. 
Tablo 7. Düzeylere göre problem kurma ölçeğinin rubrik boyutlarına göre incelenmesi.

\begin{tabular}{|c|c|c|c|c|c|c|c|c|c|c|c|c|}
\hline & \multicolumn{12}{|c|}{ Düzeyler } \\
\hline & \multicolumn{3}{|c|}{ Düzey 0} & \multicolumn{3}{|c|}{ Düzey 1} & \multicolumn{3}{|c|}{ Düzey 2} & \multicolumn{3}{|c|}{ Düzey 3} \\
\hline & 0 & 1 & 2 & 0 & 1 & 2 & 0 & 1 & 2 & 0 & 1 & 2 \\
\hline Boyutlar & $\%$ & $\%$ & $\%$ & $\%$ & $\%$ & $\%$ & $\%$ & $\%$ & $\%$ & $\%$ & $\%$ & $\%$ \\
\hline $\begin{array}{l}\text { Problemi kurarken } \\
\text { doğru strateji } \\
\text { ve yaklaşımı } \\
\text { belirleme }\end{array}$ & 83.33 & 16.66 & - & 56.42 & 43.58 & - & 35.89 & 43.58 & 20.51 & 16.07 & 64.28 & 19.64 \\
\hline $\begin{array}{l}\text { Matematiksel } \\
\text { bilgiyi tanımlama }\end{array}$ & 87.88 & 12.12 & - & 76.93 & 23.07 & - & 58.97 & 23.07 & 17.94 & 17.85 & 30.35 & 51.78 \\
\hline $\begin{array}{l}\text { Cebir bilgisini } \\
\text { günlük hayatla } \\
\text { ilişkilendirme }\end{array}$ & 96.97 & 3.03 & - & 61.54 & 38.46 & - & 41.02 & 38.46 & 20.51 & 16.07 & 64.28 & 19.64 \\
\hline $\begin{array}{l}\text { Harfi değişken } \\
\text { olarak algilama }\end{array}$ & 90.91 & 9.09 & - & 87.18 & 12.82 & - & 43.58 & 30.76 & 25.64 & 7.14 & 21.42 & 71.42 \\
\hline Denklem & 90.91 & 9.09 & - & 87.18 & 12.82 & - & 46.15 & 30.76 & 23.07 & 10.71 & 33.92 & 55.35 \\
\hline Genelleme & 74.25 & 25.75 & - & 61.53 & 30.76 & 7.6 & 41.02 & 35.89 & 23.07 & 16.07 & 57.14 & 26.78 \\
\hline Muhakeme etme & 84.85 & 15.15 & - & 58.97 & 33.33 & 7.6 & 38.46 & 38.46 & 23.07 & 14.28 & 57.14 & 28.57 \\
\hline $\begin{array}{l}\text { Eşit işareti ve } \\
\text { iliş̧kisel düşünme }\end{array}$ & 90.91 & 9.09 & - & 82.06 & 17.94 & - & 43.58 & 33.33 & 23.07 & 19.64 & 21.42 & 58.92 \\
\hline
\end{tabular}

Tablo 7 de yer alan veriler incelendiğinde düzey 0 da yer alan öğrencilerin \% 16.6 sinın problemleri kurarken doğru strateji ve yaklaşımı kısmen belirleyebildiği, genelde sistematik yaklaşamadıkları ve kavramsal hatalar yaptıkları diğerlerinin ise problem kurarken ilgisiz stratejiler kullandıkları belirlenmiştir. 0.düzey öğrencilerin \% 12.12 sinin problemleri kurarken matematiksel bilgiyi, sembol ve formül bilgisini kısmen doğru tanımladıkları \% 86,36 sının ise problemi kurarken gerek yapılandırılmış gerekse yarı yapılandırılmış problemlerde yer alan matematiksel bilgiyi tanıyamadığı, uygun sembol ve formül bilgisini kullanamadıkları gözlenmiştir. Yine bu düzeyde yer alan öğrencilerin sadece \% 3 ünün cebir bilgisini günlük hayatta nasıl kullanılacağına ilişkin bilgi ve beceri transferini kısmen yaparak serbest problemleri kısmen yazabildikleri \% 97'sinin ise bu transferi gerçekleştiremedikleri görülmüştür. Öğrencilerin \% 9.09 unun problemi kurarken verilen cebirsel ifadelerdeki harfleri kısmen değişken olarak algılayarak problemi kısmen doğru kurabildikleri, diğer öğrencilerin ise tek bir sayı değerini başlangıç noktası kabul ederek matematiksel bir problem kuramadıkları görülmüştür. Öğrencilerin ancak \% 9.09 'unun ise verilen matematiksel durumlardaki değişkenler veya objeler arasındaki ilişkileri kısmen doğru belirleyip ve bu ilişkilere uygun denklemleri kısmen oluşturup yorumladıkları sonucuna ulaşılmıştır. Örüntülere yönelik problem kurma örnekleri incelendiğinde ise düzey 0 da yer alan öğrencilerin \% 25.75' inin problem durumlarındaki örüntüyü bileșenlerine ayırıp, bu bileșenler arasındaki ilişkiyi doğru belirledikleri ancak örüntüde yer alan ilişkisel yapıyı fark ederek her terim için geçerli bir genelleme belirleyemeyerek bu genellemeye uygun bir problemi kuramadıkları, \% 70 inin ise problem kurarken verilen örüntü bilgisinin yapısını anlayamayıp bileşenleri bile bulamadıkları ve bu yanlış yorum yüzünden uygun problem kuramadıkları görülmüştür. Bu düzeydeki öğrencilerin \%15.15 inin problemi kurarken verilen duruma ilişkin kısmen uygun muhakeme yapabildiği ve uygun problem kurabildiği,(örn. uzamsal, tümevarıma dayalı, tümdengelime dayalı, istatistiksel, ve orantısal muhakeme) \% 9.09 unun eşit işaretinin bir ilişkiyi temsil ettiğini anlayamadığı ve eşit işaretini işlemsel sembol olarak görerek problem kurarken bu yönde düşünce sergilediği görülmüştür. Bu duruma örnek olarak düzey 0 da yer alan bir öğrenci kurduğu problem şekil 1'de verilmektedir. 


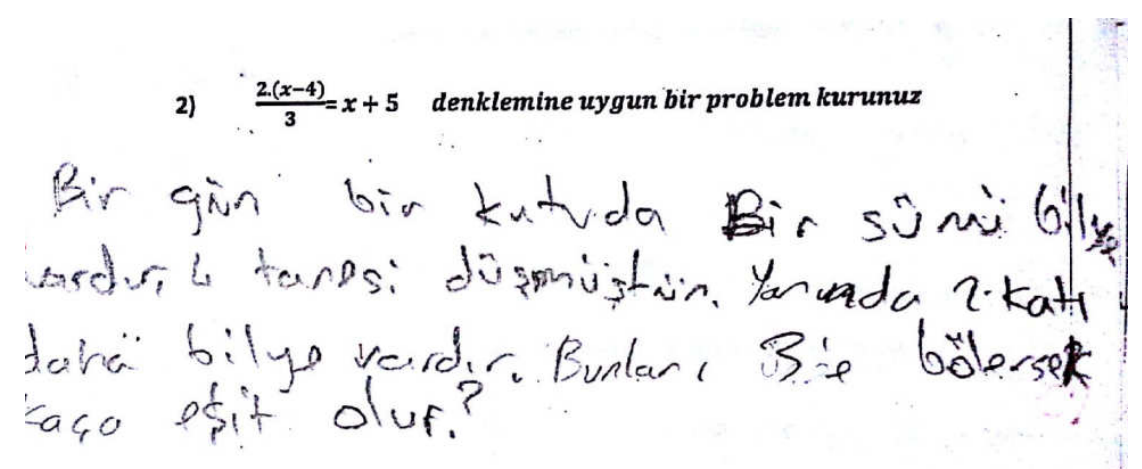

Şekil 1. Cebirsel düşünme düzeyi 0 olan öğrencinin kurduğu problem.

Şekilde görüldüğü gibi öğrenci denklemde verilen eşit işaretini ilişkisel bir sembol yerine bir işlem sembolü olarak algılamış ve bu yönde problem kurmuştur. Bilinmeyen sayıda 4 çıkartmış ancak orantısal olarak akıl yürütemeyip 2 katını almak yerine iki katını ekleyerek üçe birinin hangi sayıya eşit olduğunu sormuştur. Şekil 2 de düzey 0 da yer alan öğrencinin kurduğu problem verilmektedir.

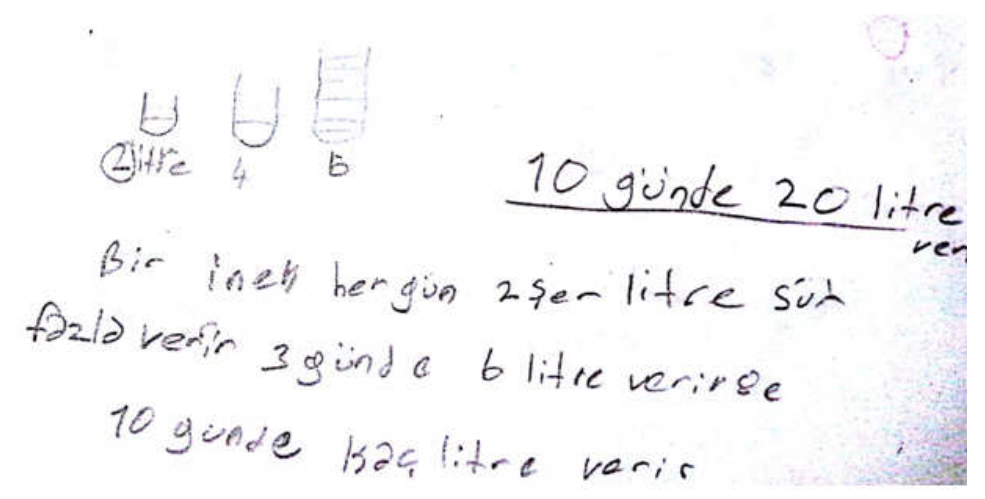

Şekil 2. Cebirsel düşünme düzeyi 0 olan serbest problem kurma deneyimi.

Serbest problem kurma durumunun bir örneği olan şekil 2 de öğrenciden örüntü içeren bir problem kurması istenmiştir. Öğrencinin kurduğu problem incelendiğinde günlük yaşamda karşılaşılması mümkün olmayan bir örnek verdiği görülmektedir. Tablo 7 de yer alan veriler incelendiğinde düzey 1 de yer alan öğrencilerin \% 43.58 inin problemleri kurarken doğru strateji ve yaklaşımı kısmen belirleyebildiği ancak bu süreçte sistematik yaklaşamadıkları ve kavramsal hatalar yaptıkları diğerlerinin ise problem kurarken ilgisiz stratejiler kullandıkları belirlenmiştir. 1. düzey öğrencilerin \% 23.07 sinin problemleri kurarken matematiksel bilgiyi, sembol ve formül bilgisini kısmen doğru tanımladıkları gözlenmiştir. Bu düzeydeki öğrencilerin sadece \% 38.46 sının cebir bilgisini günlük hayatta nasıl kullanılacağına ilişkin bilgi ve beceri transferini kısmen yaparak serbest problemleri kısmen yazabildikleri \% 12.82 sinin problemi kurarken verilen cebirsel ifadelerdeki harfleri kısmen değişken olarak algılayarak problemi kısmen doğru kurabildikleri, \% 12.82 sinin verilen matematiksel durumlardaki değişkenler veya objeler arasındaki ilişkileri kısmen doğru belirleyip ve bu ilişkilere uygun denklemleri kısmen oluşturup yorumladıkları, \% 30.76 sının verilen problem durumlarındaki örüntüyü bileşenlerine ayırıp, bu bileşenler arasındaki ilişkiyi doğru belirledikleri ancak örüntüde yer alan ilişkisel yapıyı fark ederek her terim için geçerli bir genelleme belirleyemeyerek bu genellemeye uygun bir problemi kuramadıkları, belirlenmiştir. Bu düzeydeki öğrencilerin \% 33.33.ünün problemi 
kurarken verilen duruma ilişkin kısmen uygun muhakeme yapabildiği ve uygun problem kurabildiği, \% 17.04 ünün eşit işaretinin bir ilişkiyi temsil ettiğini anlayamadığı ve eşit işaretini işlemsel sembol olarak gördüğü problem kurarken bu yönde düşünce sergilediği görülmüştür. Düzey 1 de yer alan bir öğrencinin kurduğu problem şekil 3 de verilmektedir.

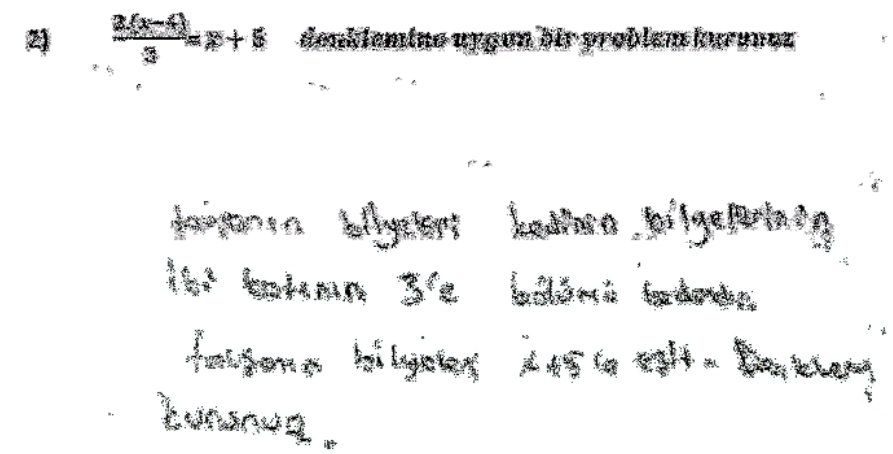

Şekil 3. Cebirsel düşünme düzeyi 1 olan öğrencinin kurduğu problem.

Öğrencinin kurduğu problem incelendiğinde problemi kurarken verilen denklemi anlayamayıp, değişkeni doğru tanımlayamadığı, yanlış muhakeme yürüterek uygun bir problem kuramadığı görülmektedir. Benzer şekilde değişkeni bir yer tutucu olarak gören, değişkenin anlamını bilmeyen ve eşit işaretini işlemsel bir sembol olarak gören ve düzey 1 de yer alan bir öğrencinin yanıtı şekil 4' de verilmektedir.

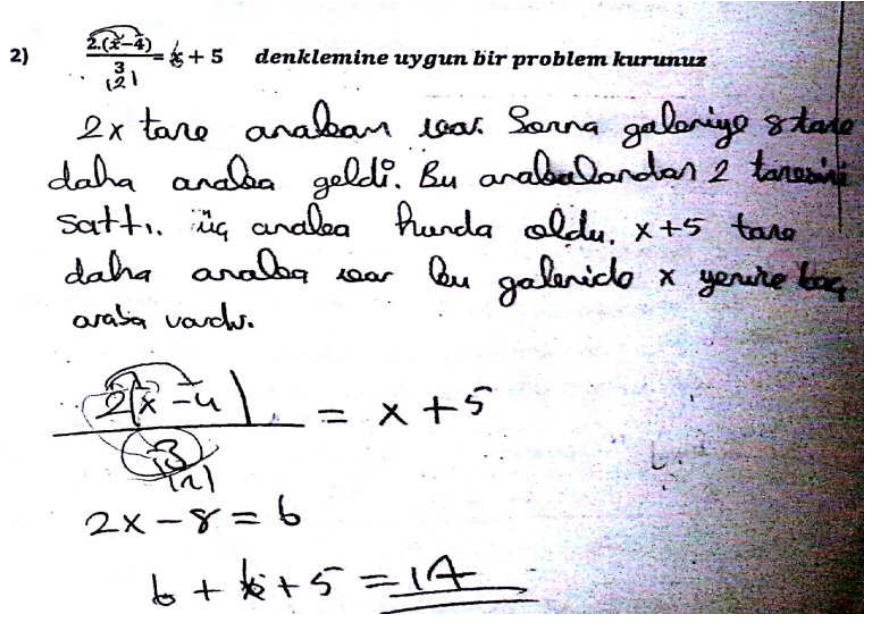

Şekil 4. Cebirsel düşünme düzeyi 1 olan öğrencinin kurduğu problem.

Tablo 7 de yer alan veriler incelendiğinde düzey 2 de yer öğrencilerin \% 20.51 inin problemleri kurarken doğru strateji ve yaklaşımı belirleyebildiği kavramsal hatalar yapmadıkları, \% 17.34 ünün problemleri kurarken matematiksel bilgiyi, sembol ve formül bilgisini doğru tanımladıkları, \% 20.51 cebir bilgisinin günlük hayatta nasıl kullanılacağına ilişkin bilgi ve beceri transferi yaparak problem kurabildiği, \% 25.64'ünün problemi kurarken verilen cebirsel ifadelerdeki harfleri değişken olarak algilayarak problemi doğru kurabildikleri, \% 23.07 sinin verilen matematiksel durumlardaki değișkenler veya objeler arasındaki ilișkileri doğru belirleyip ve bu ilişkilere uygun denklemleri oluşturup yorumlayıp doğru problem kurdukları, \% 23.07 sinin verilen problem durumlarındaki örüntüyü bileşenlerine ayırıp, bu bileșenler 
arasındaki ilişkiyi doğru belirler ve örüntüde yer alan ilişkisel yapıyı fark ederek her terim için geçerli bir genelleme belirleyip bu genellemeye uygun problemi kurabildiği, \% 23.07 sinin problemi kurarken verilen duruma ilişkin uygun muhakeme yapabildiği ve uygun problem kurabildiği, \% 23.07 sinin eşit işaretinin bir ilişkiyi temsil ettiğini anlayıp ilişkisel sembol olarak görebildiği belirlenmiştir. Düzey 2 de yer alan bir öğrencinin kurduğu problem şekil 5' de verilmektedir.

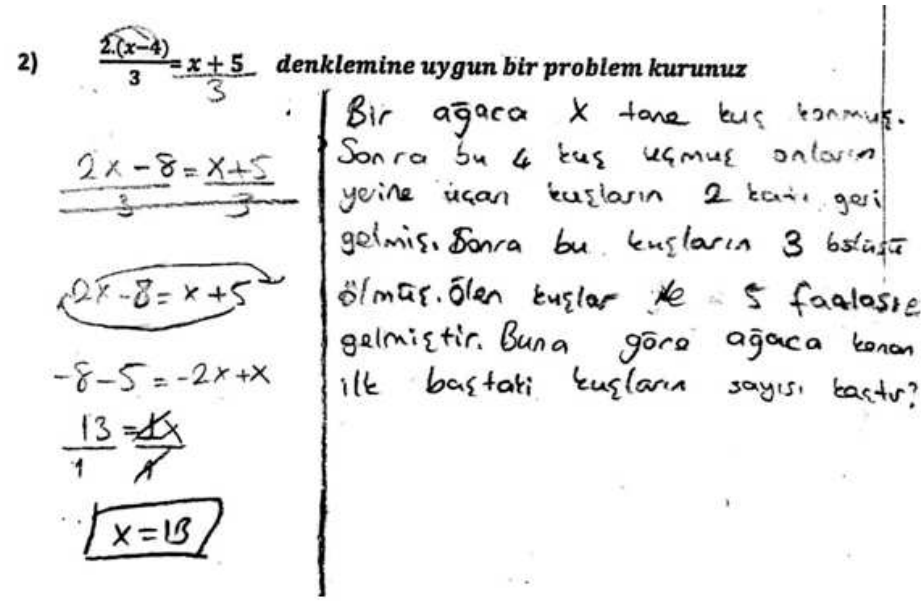

Şekil 5. Cebirsel düşünme düzeyi 2 olan öğrencinin kurduğu problem.

Şekilde görüldüğü gibi öğrencinin sahip olduğu cebir bilgisi problem kurma uygulamasına yansıyarak uygun muhakeme ile problem kurma etkinliğinde başarılı olmuştur. Tablo 7 de yer alan veriler incelendiğinde düzey 3 de yer öğrencilerin \% 19.64 ünün problemleri kurarken doğru strateji ve yaklaşımı belirleyebildiği kavramsal hatalar yapmadıkları, \% 51.78 inin problemleri kurarken matematiksel bilgiyi, sembol ve formül bilgisini doğru tanımladıkları, \% 19.64 ünün cebir bilgisinin günlük hayatta nasıl kullanılacağına ilişkin bilgi ve beceri transferi yaparak problem kurabildiği, \% 71.42 sinin problemi kurarken verilen cebirsel ifadelerdeki harfleri değişken olarak algilayarak problemi doğru kurabildikleri, \% 55.35 inin verilen matematiksel durumlardaki değişkenler veya objeler arasındaki ilişkileri doğru belirleyip bu ilişkilere uygun denklemleri oluşturup yorumlayıp doğru problem kurdukları, \% 26.78 inin verilen problem durumlarındaki örüntüyü bileșenlerine ayırıp, bu bileșenler arasındaki ilişkiyi doğru belirler ve örüntüde yer alan ilişkisel yapıyı fark ederek her terim için geçerli bir genelleme belirleyip bu genellemeye uygun problemi kurabildiği, \% 28.57 sinin problemi kurarken verilen duruma ilişkin uygun muhakeme yapabildiği ve uygun problem kurabildiği, \% 58.92 sinin eşit işaretinin bir ilişkiyi temsil ettiğini anlayıp ilişkisel sembol olarak görebildiği belirlenmiştir.

Üçüncü düzeyde yer alan öğrencilerin cebir bilgilerinin problem kurma kapsamında incelenmesi sonucu bu grup ögrencilerin büyük çoğunluğunun harfi değişken olarak algıladığı eşit işaretini ilişkisel bir sembol olarak düşündüğü genelleme ve muhakeme etmede ortalamanın üzerinde performans gösterdikleri görülmektedir. Bazı kurulan problemlerde ise daha karmaşık ve yaratıcı sonuçlar göze çarpmaktadır. Düzey 3 de yer alan bir öğrencinin kurduğu problem şekil 6' da verilmektedir. 


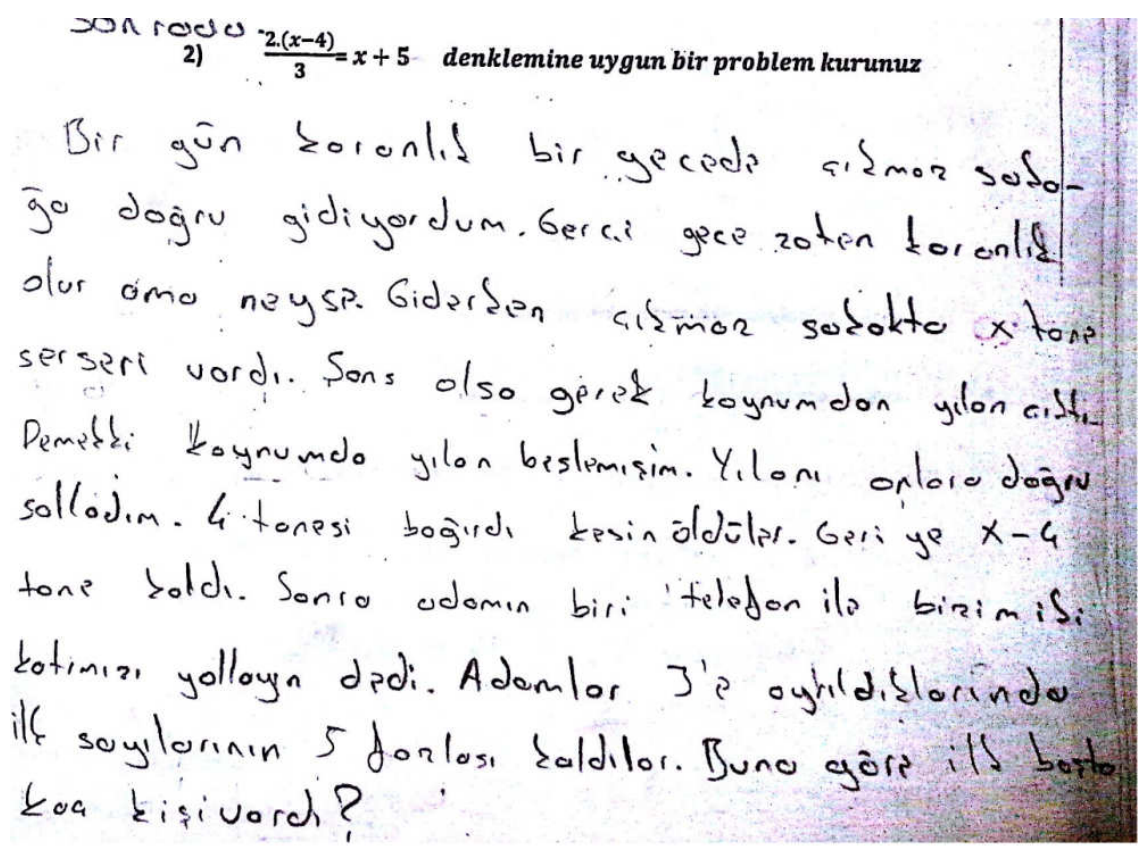

Şekil 6. Cebirsel düşünme düzeyi 3 olan öğrencinin kurduğu problem.

Cebir bilgisini günlük hayatla ilişkilendirme, problemi kurarken doğru strateji ve yaklaşımı belirleme, matematiksel bilgiyi tanımlama, harfi değişken olarak algılama, denklem, genelleme, muhakeme etme (tümevarım, tümdengelim, orantısal akıl yürütme v.b.), eşit işareti ve ilişkisel düşünme boyutlarına ait puan ortalamalarının sahip oldukları cebirsel düşünme düzeylerine göre dağılımı Tablo 8 de verilmektedir.

Tablo 8. Rubrik boyutlarına ilişkin puan ortalamaları.

\begin{tabular}{|l|l|l|l|l|}
\hline \multirow{2}{*}{ Boyutlar } & \multicolumn{4}{l}{ Düzeyler } \\
\cline { 2 - 5 } & $\begin{array}{l}\text { Düzey 0 } \\
(\mathrm{N}=66)\end{array}$ & $\begin{array}{l}\text { Düzey 1 } \\
(\mathrm{N}=39)\end{array}$ & $\begin{array}{l}\text { Düzey 2 } \\
(\mathrm{N}=39)\end{array}$ & $\begin{array}{l}\text { Düzey 3 } \\
(\mathrm{N}=56)\end{array}$ \\
\cline { 2 - 5 } & $\mathrm{X}$ & $\mathrm{X}$ & $\mathrm{X}$ & $\mathrm{X}$ \\
\hline $\begin{array}{l}\text { Problemi kurarken doğru strateji } \\
\text { ve yaklaşımı belirleme }\end{array}$ & 0.16 & 0.44 & 0.846 & 1.035 \\
\hline Matematiksel bilgiyi tanımlama & 0.12 & 0.23 & 0.59 & 1.34 \\
\hline Cebir bilgisini günlük hayatla ilişkilendirme & 0.03 & 0.38 & 0.79 & 1.04 \\
\hline Harfi değişken olarak algilama & 0.09 & 0.13 & 0.82 & 1.64 \\
\hline Denklem & 0.09 & 0.13 & 0.77 & 1.45 \\
\hline Genelleme & 0.25 & 0.46 & 0.82 & 1.11 \\
\hline Muhakeme etme & 0.15 & 0.49 & 0.85 & 1.14 \\
\hline Eşit işareti ve ilişkisel düşünme & 0.09 & 0.18 & 0.79 & 1.39 \\
\hline Toplam & 0.12 & 0.30 & 0.78 & 1.26 \\
\hline
\end{tabular}

Tablo 8'de yer alan veriler incelendiğinde öğrencilerin cebir bilgileri toplam ortalamaları sırasıyla düzey 0 için 0.12 , düzey 1 , için 0.30 , düzey 2 için 0.78 ve düzey 3 için 1.26 olarak bulunmuştur. Elde edilen bu sonuçlar öğrencilerin düşünme düzeyleri yükseldikçe cebir bilgi seviyelerini de arttığını ayrıca problem kurma performanslarının da bu doğrultuda arttığını ortaya koymaktadır. 


\section{Sonuç tartışma ve öneriler}

Bu çalıșmanın sonucunda

- Katılımcıların \% 33 ünün düzey 0 da, \% 19.5'inin düzey 1 de, \% 19.5'inin düzey 2 , \% 28'inin düzey 3 de yer aldığı, düzey 4 de ise hiçbir öğrencinin bulunmadiğ 1 ,

- Farklı cebirsel düşünme düzeylerine sahip öğrencilerin problem kurma beceri puan ortalamalarının Düzey 0 için 3.55, Düzey 1 için 11.26, Düzey 2 için 10.10, Düzey 3 için 13.86 olduğu ve problem kurma beceri puan ortalamalarının öğrencilerin sahip olduğu cebirsel düşünme düzeylerine göre anlamlı şekilde farklılık gösterdiği

- Buna göre öğrencilerin sahip oldukları cebirsel düşünme düzeyinin problem kurma başarılarını etkilediği cebirsel düşünmesi düşük düzeyde olan öğrencilerin problem kurmada başarısız olduğu

- Ayrı ayrı her düzeydeki öğrencilerin problem kurma ölçeğinde farklı cebir bilgisine sahip olduğu genel olarak öğrencilerin \% 9.5 inin problemleri kurarken doğru strateji ve yaklaşımı belirleyebildiği kavramsal hatalar yapmadıkları, \% 18 ' inin problemleri kurarken matematiksel bilgiyi, sembol ve formül bilgisini doğru tanımladıkları, \% 5.5 'inin cebir bilgisinin günlük hayatta nasıl kullanılacağına ilişkin bilgi ve beceri transferi yaparak problem kurabildiği, \% 25 inin problemi kurarken verilen cebirsel ifadelerdeki harfleri değişken olarak algilayarak problemi doğru kurabildikleri, \% 19.5 inin verilen matematiksel durumlardaki değişkenler veya objeler arasındaki ilişkileri doğru belirleyip ve bu ilişkilere uygun denklemleri oluşturup yorumlayıp doğru problem kurdukları, \% 13.5 inin verilen problem durumlarındaki örüntüyü bileșenlerine ayırıp, bu bileşenler arasındaki ilişkiyi doğru belirler ve örüntüde yer alan ilişkisel yapıyı fark ederek her terim için geçerli bir genelleme belirleyip bu genellemeye uygun problemi kurabildiği, \% 14 ünün problemi kurarken verilen duruma ilişkin uygun muhakeme yapabildiği ve uygun problem kurabildiği, \% 20 sinin eşit işaretinin bir ilişkiyi temsil ettiğini anlayıp ilişkisel sembol olarak görebildiği belirlenmiştir.

Buna göre cebirsel düşünme düzeyi 2 ve altında bulunan öğrencilerin problem kurma becerisinin yetersiz olmasının bu öğrencilerin çoğunun harfi yer tutucu olarak görmesi, eşit işaretini işlemsel bir sembol olarak düşünmeleri [21] nedeniyle problem durumlarını analiz edemeyip problem kuramadıkları, yanlış muhakeme yürüterek uygun denklem ve eşitlikleri oluşturamadıkları gözlenmiştir. Öğrencilerin \% 75 inin problemi kurarken verilen cebirsel ifadelerdeki harfleri değişken olarak algılamadıkları sayısal değerler vererek problem kurmaya çalıştıkları gözlenmiştir. Benzer sonuçlar Gökkurt, Örnek, Hayat ve Soylu tarafından yapılan araştırmanın sonuçlarıyla da benzerlik göstermektedir [33]. Ortaokul öğrencilerinin problem kurma ve çözme becerilerinin incelendiği araştırmada öğrencilerin problem kurma becerilerinin istenilen düzeyde olmadığı öğrencilerin çoğunun ya verilen problemde sayısal değerleri değiştirerek problemi aynen yazdığı veya çözümü olmayan mantıksız problemler kurduğu belirlenmiştir. Bunun yanında öğrencilerin pek çoğunun cebir bilgisinin yeterli düzeyde olmadığı cebirsel düşünme düzeylerinin düzey 2 ve altında olduğu sonucu öğretim programı uygulamalarının incelenmesi gerekliliğini ortaya koymaktadır. Nitekim Dikkartın-Övez tarafından yapılan çalışmanın sonuçlarında ortaokul matematik dersi 
cebir öğrenme alanı kazanımlarının sadece ortalama \% 52 sine ulaşılmış olmasına ilişkin bulgu öğrencilerin cebir bilgilerinin ve cebirsel düşünme düzeylerinin gelişiminde öğretim programından veya öğretim sürecinden kaynaklanan sorunlar olduğunu düşündürmektedir [18]. Ayrıca öğrencilerin öğretim programının geliştirilmesi hedeflenen beceriler arasında gösterilen problem kurmaya yabancı olmaları öğretim programında problem kurma etkinliklerinin eksikliğini göstermektedir. $\mathrm{Bu}$ sonuç yapılan pek çok araştırmada da ortaya konulmuş bir bulgudur. Yapılan çalışmalar öğretim uygulamalarını düzenlemekle görevli olan öğretmen ve öğretmen adaylarının da problem kurma etkinliklerine yabancı olduğunu ortaya koymaktadır [34]. Öğretmenlerin ve öğretmen adaylarının problem kurma konusunda bilgi ve becerilerinin geliştirilmesi önerilmektedir. Bu doğrultuda sınıf içi ve biçimlendirici değerlendirme aracı olarak problem kurma öğretmenlere tanıtılabilir. Öğrencilerin problem kurma becerilerini öğretim programının öğretim sürecindeki başarısını değerlendirme ölçeği olarak değerlendiren çalışmalar bu fikri destekler niteliktedir [9]. Diğer taraftan sınıf içinde yapılacak problem kurma çalışmaları ile öğrencilerin cebir bilgilerindeki eksiklikler, yanlış kavramalar ortaya konularak verilecek geri dönüt ve gelişimsel uygulamalarla öğrencilerin cebirsel düşünme düzeylerinin ve cebir bilgilerinin geliştirilmesine yönelik deneysel çalışmalar yapılması ve modeller ortaya konulması önerilmektedir.

\section{Kaynaklar}

[1] MEB., Ortaokul Matematik Dersi 5-8. Sınıflar Öğretim Programı ve Kılavuzu. Ankara, (2017).

[2] NCTM., Principals and Standarts for School Mathematics, Reston, Va: National counsil of Teachers of Mathematics Pub., (2000).

[3] Lin, P. J., Supporting Teachers on Designing Problem-Posing Tasks as a Tool of Assessment to Understand Students' Mathematical Learning. International Group for the Psychology of Mathematics Education, (2004).

[4] Cai, J., \& Hwang, S., Generalized and generative thinking in US and Chinese students' mathematical problem solving and problem posing. Journal of Mathematical Behavior, 21, 401-421, (2002).

[5] Singer, F. M., Voica, C., \& Pelczer, I., Cognitive styles in posing geometry problems: implications for assessment of mathematical creativity. ZDM, 49(1), 37-52., (2017).

[6] Singer, F. M., The dynamic infrastructure of mind-A hypothesis and some of its applications. New Ideas in Psychology, 27(1), 48-74, (2009).

[7] Singer, F. M., \& Voica, C., A problem-solving conceptual framework and its implications in designing problem-posing tasks. Educational Studies in Mathematics, 83(1), 9- 26, (2013).

[8] Munroe, K. L., Assessment of a Problem Posing Task in a Jamaican Grade Four Mathematics Classroom. Journal of Mathematics Education at Teachers College, 7(1), (2016).

[9] Lin, K. M., \& Leng, L. W., Using problem-posing as an assessment tool. In 10th Asia-Pacific Conference on Giftedness, Singapore, (2008).

[10] Lowrie, T., Young children posing problems: The influence of teacher intervention on the type of problems children pose. Mathematics Education Research Journal, 14, 87-98, (2002). 
[11] Lavy, I., \& Bershadsky, I., Problem posing via "what if not?" strategy in solid geometry-a case study. Journal of Mathematical Behavior, 22, 369-38,. (2003).

[12] Cai, J., Singaporean students' mathematical thinking in problem solving and problem posing: An exploratory study. International Journal Mathematics Education Science Technology, 34, 719-737, (2003).

[13] Stoyanova, E., Extending students' problem solving via problem posing. The Australian Mathematics Teacher, 55(3), 29-35, (1999).

[14] Yuan, X., \& Sriraman, B., An exploratory study of relationships between students' creativity and mathematical problem-posing abilities. In B. Sriraman \& K. H. Lee (Eds.), The elements of creativity and giftedness in mathematics (pp. 5-28). Rotterdam, The Netherlands: Sense, (2011).

[15] Barlow, A. T., \& Cates, J. M., The impacts of problem posing on elementary teachers' belief about mathematics and mathematics teaching. School Science and Mathematics, 106, 64-73, (2006).

[16] Cunningham, R. F.,Problem posing: An opportunity for increasing student responsibility. Mathematics and Computer Education, 38(1), 83-39, (2004).

[17] Silver, E. A., \& Cai, J., An analysis of arithmetic problem posing by middle school students. Journal for Research in Mathematics Education, 27, 521-539, (1996).

[18] Dikkartın Övez, F.T., Matematik Öğretim Programlarının Değerlendirilmesi (Cebir Öğrenme Alanı), (Doktora Tezi, Yayınlanmamış), Fen Bilimleri Enstitüsü, Balıkesir Üniversitesi, (2012).

[19] Karasar, N., Bilimsel araştırma yöntemi. Ankara: Nobel Yayınları, (2015).

[20] Altun, M., Illköğretim İkinci Kademede Matematik Öğretimi. Bursa: Aktüel,(2007).

[21] Hart, K.M., Brown, M.L., Kuchermann, D.E., Kerslach, D., Ruddock, G. \& Mccartney, M., Children's Understanding of Mathematics: 11-16, General Editor K.M. Hart, The CSMS Mathematics Team, (1998).

[22] Stoyanova, E. \& Ellerton, N. F., A framework for research into students' problem posing. In P. Clarkson (Ed.), Technology in Mathematics Education (518-525). Melbourne: Mathematics Education Research Group of Australasia,(1996).

[23] Akkan, Y., Çakıroğlu, Ü., \& Güven, B., Equation forming and problem posing abilities of 6th and 7th grade primary school students. Mehmet Akif Ersoy Üniversitesi Eğitim Fakültesi Dergisi, 9(17), 41-55, (2009).

[24] Van De Walle, J. A., Karp, K. S. ve Bay-Williams, J., M.,Ilkokul ve Ortaokul Matematiği, Gelişimsel Yaklaşımla Öğretim. Nobel Yayın Dağıtım, (2014).

[25] Yurdagül, H., Ölçek Geliştirme Çalışmalarında Kapsam Geçerlik İndeksinin Kullanımı. 14. Eğitim Bilimleri Kongresi, Pamukkale Üniversitesi, Denizli, (2005).

[26] Veneziano L. ve Hooper JA., method for quantifying content validity of healthrelated questionnaires. American Journal of Health Behavior, 21(1):67-70, (1997).

[27] Stoyanova, E., Problem-problem strategies used by years 8 and 9 students. AAMT Standards for Excellence in Teaching Mathematics in Australian Schools, 61(3), 6-11, (2005).

[28] Kılıç, Ç., Pre-service primary teachers' free problem-posing performances in the context of fractions: An example from Turkey. The Asia-Pacific Education Researcher, 22(4), 677-686, (2013). 
[29] Turhan, B., Problem kurma yaklaşımı ile gerçekleştirilen matematik öğretiminin ilköğretim 6. sınıf öğrencilerinin problem çözme başarıları, problem kurma becerileri ve matematiğe yönelik görüşlerine etkisinin incelenmesi. (Yüksek lisans tezi), Anadolu Üniversitesi, Eğitim Bilimleri Enstitüsü, Eskişehir, (2011).

[30] Lee, C.H., The effect of problem posing on fifth graders understanding of semantic structure in arithmetic word problem and on their problem solving capability. (Unpublished master thesis). National Taipei Teachers College, Taipei, Taiwan, (2002).

[31] NCTM, Principals and Standarts for School Mathematics, Reston, Va: National counsil of Teachers of Mathematics Pub.,(1989).

[32] Şencan, H.,Sosyal ve Davranışsal Ölçmelerde Güvenirlik ve Geçerlilik, Ankara: Seçkin Yayınları, (2005).

[33] Gökkurt, B., Örnek, T., Hayat, F., \& Soylu, Y., Öğrencilerin Problem Çözme ve Problem Kurma Becerilerinin Değerlendirilmesi. Bartın Üniversitesi Eğitim Fakültesi Dergisi, 4(2), 751-774, (2015).

[34] Crespo, S., \& Sinclair, N., What makes problem mathematically interesting? Inviting prospective teachers to pose better problems. Journal of Mathematics Teacher Education, 11, 395-415, (2008). 
DIKKARTIN ÖVEZ F.T., ÇINAR B.A.

\section{Ek1. Rubrik}

\begin{tabular}{|c|c|c|c|}
\hline Boyutlar & 2 & 1 & 0 \\
\hline $\begin{array}{l}\text { Problemi kurarken doğru } \\
\text { strateji ve yaklaşımı } \\
\text { belirleyebilme }\end{array}$ & $\begin{array}{l}\text { Problemi kurarken doğru } \\
\text { strateji ve yaklaşımı } \\
\text { belirleyebilir } \\
\text { kavramsal hata yapmaz }\end{array}$ & $\begin{array}{l}\text { Problemi kurarken doğru } \\
\text { strateji ve yaklaşımı } \\
\text { kısmen belirleyebilir } \\
\text { Sistematik yaklaşamaz, } \\
\text { kavramsal hatalar yapar }\end{array}$ & $\begin{array}{l}\text { Problemi kurarken ilgisiz } \\
\text { strateji kullanır Kavramsal } \\
\text { hata yapar }\end{array}$ \\
\hline $\begin{array}{ll}\text { Matematiksel } & \text { bilgiyi } \\
\text { doğru tamınlama } & \end{array}$ & $\begin{array}{l}\text { Problemi kurarken } \\
\text { matematiksel bilgiyi } \\
\text { doğru tanımlar }\end{array}$ & $\begin{array}{l}\text { Problemi kurarken } \\
\text { matematiksel bilgiyi } \\
\text { bazen doğru tanımlar, } \\
\text { sembol ve formül bilgisini } \\
\text { kısmen tanımlar }\end{array}$ & $\begin{array}{l}\text { Problemi kurarken } \\
\text { matematiksel bilgiyi } \\
\text { tanımlayamaz }\end{array}$ \\
\hline $\begin{array}{l}\text { Cebir bilgisini günlük } \\
\text { hayatla ilişkilendirme }\end{array}$ & $\begin{array}{l}\text { Cebir bilgisinin günlük } \\
\text { hayatta nasıl } \\
\text { kullanılacağına ilişkin } \\
\text { bilgi ve beceri transferi } \\
\text { yapar }\end{array}$ & $\begin{array}{l}\text { Cebir bilgisinin günlük } \\
\text { hayatta nasıl } \\
\text { kullanılacağına ilişkin } \\
\text { bilgi ve beceri transferini } \\
\text { kısmen yapar }\end{array}$ & $\begin{array}{l}\text { Cebir bilgisinin günlük } \\
\text { hayatta nasıl kullanılacağına } \\
\text { ilişkin bilgi ve beceri } \\
\text { transferini yapamaz }\end{array}$ \\
\hline $\begin{array}{l}\text { Harfin değişken olarak } \\
\text { algılaması }\end{array}$ & $\begin{array}{l}\text { Problemi kurarken verilen } \\
\text { cebirsel ifadelerdeki } \\
\text { harfleri değişken olarak } \\
\text { algılayarak problemi } \\
\text { doğru kurar }\end{array}$ & $\begin{array}{l}\text { Problemi kurarken verilen } \\
\text { cebirsel ifadelerdeki } \\
\text { harfleri kısmen değişken } \\
\text { olarak algılayarak } \\
\text { problemi kısmen doğru } \\
\text { kurar }\end{array}$ & $\begin{array}{l}\text { Problemi kurarken verilen } \\
\text { cebirsel ifadelerdeki harfleri } \\
\text { değişken olarak algilayamaz. } \\
\text { Matematiksel bir problem } \\
\text { kuramaz }\end{array}$ \\
\hline Denklem bilgisi & $\begin{array}{l}\text { Verilen matematiksel } \\
\text { durumlardaki değişkenler } \\
\text { veya objeler arasındaki } \\
\text { ilişkileri doğru belirler ve } \\
\text { bu ilişkilere uygun } \\
\text { denklemleri oluşturup } \\
\text { yorumlar }\end{array}$ & $\begin{array}{l}\text { Verilen matematiksel } \\
\text { durumlardaki değişkenler } \\
\text { veya objeler arasındaki } \\
\text { ilişkileri kısmen doğru } \\
\text { belirler ve bu ilişkilere } \\
\text { uygun denklemleri } \\
\text { kısmen oluşturup } \\
\text { yorumlar }\end{array}$ & $\begin{array}{l}\text { Verilen matematiksel } \\
\text { durumlardaki değişkenler } \\
\text { veya objeler arasındaki } \\
\text { ilişkileri belirleyemez ve } \\
\text { kullanamaz. }\end{array}$ \\
\hline Genelleme & $\begin{array}{l}\text { Verilen problem } \\
\text { durumlarındaki örüntüyü } \\
\text { bileşenlerine ayırırı, bu } \\
\text { bileşenler arasındaki } \\
\text { ilişkiyi doğru belirler ve } \\
\text { örüntüde yer alan ilişkisel } \\
\text { yapıyı fark ederek her } \\
\text { terim için geçerli bir } \\
\text { genelleme belirleyip bu } \\
\text { genellemeye uygun } \\
\text { problemi kurar. }\end{array}$ & $\begin{array}{l}\text { Verilen problem } \\
\text { durumlarındaki örüntüyü } \\
\text { bileşenlerine ayırırı, bu } \\
\text { bileşenler arasındaki } \\
\text { ilişkiyi doğru belirler } \\
\text { ancak örüntüde yer alan } \\
\text { ilişkisel yapıyı fark ederek } \\
\text { her terim için geçerli bir } \\
\text { genelleme belirleyemez } \\
\text { uygun problemi kurar. }\end{array}$ & $\begin{array}{l}\text { Problemi kurarken verilen } \\
\text { problem durumlarındaki } \\
\text { örüntüyü bilgisini } \\
\text { tanımlayıp problem kuramaz }\end{array}$ \\
\hline Muakeme & $\begin{array}{l}\text { Problemi kurarken } \\
\text { verilen duruma ilişkin } \\
\text { uygun muhakeme } \\
\text { yapabilir.(örn. uzamsal, } \\
\text { tümevarıma dayalı, } \\
\text { tümdengelime dayalı, } \\
\text { istatistiksel, ve orantısal } \\
\text { muhakeme) }\end{array}$ & $\begin{array}{l}\text { Problemi kurarken } \\
\text { verilen duruma ilişkin } \\
\text { kısmen uygun muhakeme } \\
\text { yapabilir.(örn. uzamsal, } \\
\text { tümevarıma dayalı, } \\
\text { tümdengelime dayalı, } \\
\text { istatistiksel, ve orantısal } \\
\text { muhakeme) }\end{array}$ & $\begin{array}{l}\text { Problemi kurarken verilen } \\
\text { duruma ilişkin uygun } \\
\text { muhakeme yapamaz }\end{array}$ \\
\hline $\begin{array}{l}\text { Eşit işareti ve iliş̧isel } \\
\text { düşünme }\end{array}$ & $\begin{array}{l}\text { Eşit işaretinin bir ilişkiyi } \\
\text { temsil ettiğini anlar, } \\
\text { ilişkisel sembol olarak } \\
\text { görür ve ilişkisel } \\
\text { düşünebilir. }\end{array}$ & $\begin{array}{l}\text { Eşit işaretinin bir ilişkiyi } \\
\text { temsil ettiğini anlamaz } \\
\text { eşit işaretini” ilişkisel } \\
\text { sembolden ziyade } \\
\text { işlemsel sembol olarak } \\
\text { görüp ilişkisel düşünemez }\end{array}$ & $\begin{array}{l}\text { Eşit işaretinin anlayamaz ve } \\
\text { ilişsisel düşünemez }\end{array}$ \\
\hline
\end{tabular}

